\title{
Timothy silage with low dietary cation-anion difference fed to nonlactating cows
}

\author{
E. Charbonneau, ${ }^{* 1}$ P. Y. Chouinard, ${ }^{*}$ G. F. Tremblay,† G. Allard, $\ddagger$ and D. Pellerin* \\ *Département des Sciences Animales, Université Laval, Québec, QC, Canada G1V 0A6 \\ †Agriculture and Agri-Food Canada, Québec, QC, Canada G1V 2J3 \\ ‡Département de Phytologie, Université Laval, Québec, QC, Canada G1V OA6
}

\section{ABSTRACT}

Decreasing the dietary cation-anion difference (DCAD) by using anion sources before calving reduces hypocalcemia in cows at calving. Reduced DCAD from $\mathrm{CaCl}_{2}$-fertilized timothy hay achieves similar results, but the effects of feeding low-DCAD forage as silage have not been determined. The objective of this study was to evaluate the effect of low-DCAD timothy silage on dry cows. Six nonlactating and nonpregnant Holstein cows were used in a replicated $3 \times 3$ Latin square. Treatments were 1) control diet (DCAD $=232 \mathrm{mEq} /$ $\mathrm{kg}$ of dry matter, DM); 2) low-DCAD diet using a lowDCAD timothy silage (LDTS; DCAD $=-21 \mathrm{mEq} / \mathrm{kg}$ of $\mathrm{DM}$ ); and 3) low-DCAD diet using a fermentation by-product (LDBP; DCAD $=-32 \mathrm{mEq} / \mathrm{kg}$ of DM). Differences between dietary treatments were considered statistically significant at $P \leq 0.05$ and tendencies were noted when $0.05<P<0.10$. Compared with the control, feeding LDTS tended to decrease DM intake (10.6 vs. $12.5 \mathrm{~kg} / \mathrm{d}$ ) and decreased urinary pH (6.15 vs. 8.18) as well as apparent digestibility of DM (67 vs. $69 \%$ ). Blood $\mathrm{pH}(7.37$ vs. 7.42$), \mathrm{HCO}_{3}{ }^{-}$(25.3 vs. $\left.27.5 \mathrm{mM}\right)$, and base excess ( 0.4 vs. $3.1 \mathrm{mM}$ ) were decreased, and blood $\mathrm{Cl}^{-}$(29.6 vs. $29.1 \mathrm{mg} / \mathrm{dL}$ ) was increased. Apparently absorbed $\mathrm{Na}$ and $\mathrm{Cl}$ were higher and apparently absorbed K, P, and digested ADF were lower for LDTS compared with the control. Both LDTS and LDBP resulted in similar DM intake. Urinary $\mathrm{pH}$ tended to be higher (6.15 vs. 5.98) and percentage of digested DM was lower ( 67 vs. $70 \%$ ) with LDTS compared with LDBP. Blood ionized Ca (5.3 vs. $5.4 \mathrm{mg} / \mathrm{dL})$ tended to be lower and blood $\mathrm{Cl}^{-}$(29.6 vs. $\left.30.1 \mathrm{mg} / \mathrm{dL}\right)$ was lower, whereas blood $\mathrm{pH}$ (7.37 vs. 7.33$), \mathrm{HCO}_{3}{ }^{-}(25.3$ vs. $21.5 \mathrm{mM}$ ), and base excess $(0.4$ vs. $-3.8 \mathrm{mM}$ ) were higher with LDTS compared with LDBP. Apparent absorption of $\mathrm{Na}, \mathrm{Cl}, \mathrm{S}$, and $\mathrm{P}$, as well as apparent digestion of acid detergent fiber, neutral detergent fi-

Received July 21, 2008.

Accepted December 1, 2008.

${ }^{1}$ Corresponding author: edith.charbonneau@fsaa.ulaval.ca ber, and $\mathrm{N}$ were lower, and $\mathrm{K}, \mathrm{Cl}, \mathrm{S}, \mathrm{P}, \mathrm{Mg}$, and $\mathrm{N}$ were less retained with LDTS compared with LDBP. Results confirm that low-DCAD timothy silage can be used to produce a compensated metabolic acidosis by decreasing the DCAD of rations served to nonlactating dairy cows.

Key words: nonlactating cow, dietary cation-anion difference, silage, mineral absorption

\section{INTRODUCTION}

Hypocalcemia is an important problem in dairy cattle around parturition because of rapid increases in Ca requirements. Clinical hypocalcemia, or milk fever, can be fatal if not treated and both clinical and subclinical forms are detrimental to cows by increasing the risk of other metabolic disorders (Huber et al., 1981; Oetzel et al., 1988). Milk fever incidence can be lowered by decreasing the DCAD of rations fed during the transition period (Dishington, 1975; Charbonneau et al., 2006; Lean et al., 2006). Anionic salts (Vagnoni and Oetzel, 1998), commercial products (Vagnoni and Oetzel, 1998), and hydrochloric acid (Goff and Horst, 1998; Goff et al., 2004) can effectively lower DCAD. In geographic areas where high $\mathrm{Ca}$ and $\mathrm{K}$ concentrations are common in basal diets, decreasing DCAD is more necessary. Decreasing the $\mathrm{K}$ concentration of forages was proposed as a method of lowering milk fever incidence (Horst and Goff, 1997; Horst et al., 1997). To explore this option, an experiment has been conducted to evaluate DCAD of forage species (Tremblay et al., 2006) and indicated timothy as the species with the lowest DCAD because it is naturally low in $\mathrm{K}$. The DCAD of timothy forage can be further decreased with $\mathrm{CaCl}_{2}$ fertilization (Pelletier et al., 2007).

In previous experiments, low-DCAD timothy hays effectively modified cow metabolism as indicated by reduced urine $\mathrm{pH}$ and differences in several blood components (Charbonneau et al., 2008; Penner et al., 2008). Charbonneau et al. (2008) observed a better response to a simulated hypocalcemia using EDTA, and Penner et al. (2008) observed higher blood ionized 
$\mathrm{Ca}$ after calving for cows fed a low-DCAD instead of a control timothy hay. In one study (Charbonneau et al., 2008), the diet based on a low-DCAD timothy hay was also compared with a low-DCAD $\mathrm{HCl}$ diet; similar results were observed except for a tendency toward a higher DMI when the low-DCAD timothy hay was used instead of $\mathrm{HCl}$. In these 2 studies (Charbonneau et al., 2008; Penner et al., 2008), the low-DCAD timothy hay did not affect DMI compared with a control timothy hay. This suggests that using timothy hay to decrease forage DCAD may avoid the negative effects on DMI associated with using anionic products.

Few studies report mineral absorption and retention with different levels of DCAD. Charbonneau et al. (2008) reports lower $\mathrm{K}$ and higher $\mathrm{Cl}$ apparent absorption and higher $\mathrm{Cl}$ apparent retention when DCAD was decreased using a low-DCAD timothy hay instead of a normal-DCAD ration. When low-DCAD hay was compared with $\mathrm{HCl}$ to decrease DCAD, the major differences noted were lower $\mathrm{Na}$ and higher $\mathrm{S}$ apparent absorptions. The lack of difference for $\mathrm{Ca}$, $\mathrm{P}$, and $\mathrm{Mg}$ apparent absorption in the Charbonneau et al. (2008) study is comparable to Wang and Beede (1990) and Kume et al. (2001), but not to Schonewille et al. (1994b), which reports an increase in Ca apparent absorption and a tendency for an increase in $\mathrm{Mg}$ apparent absorption with a low-DCAD diet. More research is needed to better understand how mineral absorption and retention relate to variations in DCAD.

In our previous experiment (Charbonneau et al., 2008), $\mathrm{HCl}$ was used as a positive control for easier comparison to other treatments in an experimental context. However, $\mathrm{HCl}$ is not representative of what is given to transition cows on most dairy farms. Moreover, on many commercial farms, grass hay is often partly replaced by grass or corn silages or a mixture of both during the transition period. Differences in nutrient digestion have been observed between hay and silage (Broderick, 1985). Variations for mineral absorption were not measured but results for other nutrients suggest there could be differences. Most minerals used in DCAD equations are well absorbed (NRC, 2001), but results from several experiments (Wang and Beede, 1990; Delaquis and Block, 1995; Charbonneau et al., 2008) have suggested that mineral absorption could be influenced by the state of the animal, and nonlactating cows may not absorb some minerals as efficiently as lactating animals. There is a need to verify the effect of feeding low-DCAD forage conserved as silage on acidbase status of nonlactating cows.

Our hypothesis was that timothy fertilized with $\mathrm{CaCl}_{2}$ and conserved as silage would be as efficient at preventing hypocalcemia as other products that decrease the DCAD of dry-cow rations fed during the transition period. The objective of this study was to verify the effect of decreasing DCAD of a ration using low-DCAD silage compared with a commercial anionic product on DMI, capacity to create compensated metabolic acidosis, and apparent absorption of minerals. Using a control diet, we evaluated the capacity of low-DCAD timothy silage to modify blood and urine parameters and evaluated its effect on DMI. We also compared the low-DCAD timothy silage diet with a positive control, where the DCAD was decreased using a commercial anionic fermentation by-product. In addition to DMI, urine and blood parameters, apparent digestibility of fibers and $\mathrm{N}$, apparent absorption of minerals, and apparent retention of $\mathrm{N}$ and minerals were measured for all 3 treatments.

\section{MATERIALS AND METHODS}

\section{Silage Production}

Two types of silage (Table 1) were produced on 2 predominantly timothy $(>90 \%)$ fields established in 2002. The low-DCAD timothy silage was produced on a field with a low soil $\mathrm{K}$ content $(101 \mathrm{~kg} / \mathrm{ha})$ and the high-DCAD timothy silage was produced on a field with a soil K content of $289 \mathrm{~kg} / \mathrm{ha}$. Before the start of spring growth, both fields received $80 \mathrm{~kg}$ of $\mathrm{N} / \mathrm{ha}$ and, based on the recommendation of Pelletier et al. (2007), the field where the low-DCAD timothy silage was produced was also fertilized with $140 \mathrm{~kg}$ of $\mathrm{Cl} / \mathrm{ha}$ as $\mathrm{CaCl}_{2}$. Timothy spring growth was cut at the early-heading stage of development using a disc mower equipped with a roller-type conditioner (New Holland Discbine, model 1432, New Holland, PA). The forage was wilted in the field until it reached $35 \%$ DM. It was then chopped and stored in a plastic bag (Bag All, Klerk's Plastic Products Manufacturing Inc., Richburg, SC) with a silage compactor (Roto Press, Sioux Automation, Sioux City, IA). A total of approximately $40 \mathrm{t}$ of chopped forage was ensiled in 2 plastic-bag silos.

\section{Cows, Diets, and Experimental Design}

Six multiparous nonpregnant and nonlactating Holstein cows were assigned to a replicated $3 \times 3$ Latin square design with 2 -wk periods. All cows were fed, as TMR, timothy silage, corn silage, ground corn, and a mixture of vitamins and minerals (Table 2). Treatments were 1) high-DCAD control diet; 2) low-DCAD diet, using the low-DCAD timothy silage (LDTS); and 3) low-DCAD diet, using a fermentation by-product (BioChlor, Church and Dwight Co. Inc., Princeton, NJ; LDBP). Because diets formulated with only the highDCAD timothy silage had a cation-anion difference too 
Table 1. Chemical composition of silages and experimental diets

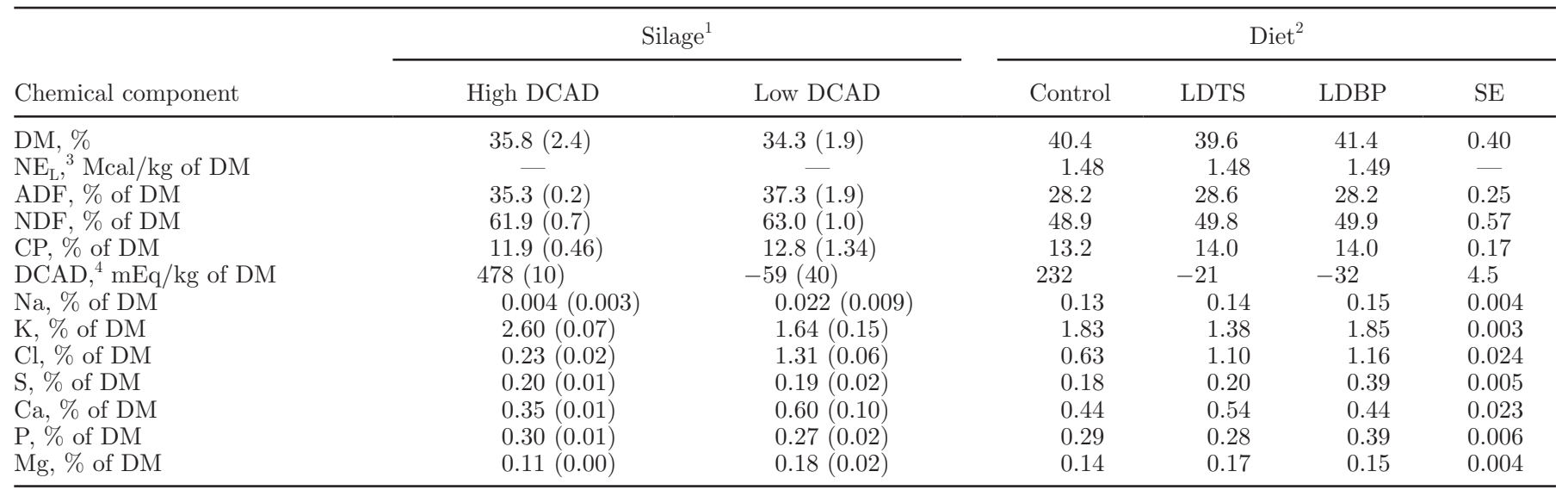

${ }^{1}$ Mean (SD).

${ }^{2}$ Control $=$ high-DCAD treatment; LDTS $=$ low-DCAD treatment using low-DCAD timothy silage; LDBP $=$ low-DCAD treatment using a fermentation by-product.

${ }^{3}$ Estimated using the average composition of diet and cow parameters of the treatment with the NRC (2001) model.

${ }^{4} \mathrm{DCAD}(\mathrm{mEq} / \mathrm{kg}$ of $\mathrm{DM})=\left(\mathrm{Na}^{+}+\mathrm{K}^{+}\right)-\left(\mathrm{Cl}^{-}+\mathrm{S}^{2-}\right)$.

high to be decreased with the fermentation by-product alone, and to follow the manufacturer's recommendation of an optimal inclusion of 0.9 to $1.1 \mathrm{~kg}$ of the fermentation by-product/d per cow, the low-DCAD timothy silage had to be mixed with the high-DCAD timothy silage in the proportion of $1: 2$ in the control and LDBP diets (Table 2). Both the control and LDTS diets included a mixture of soybean meal and corn gluten meal as a protein supplement, whereas the LDBP diet had only the fermentation by-product as a protein supplement. Diets were formulated based on NRC (2001) recommendations for transition cows (Table 1) and provided similar levels of $\mathrm{NE}_{\mathrm{L}}(1.48 \mathrm{Mcal} / \mathrm{kg}$ of $\mathrm{DM})$ and $\mathrm{CP}(13.8 \%$ of $\mathrm{DM})$. Rations were fed once a day in the morning to provide $10 \%$ orts on an asfed basis according to the previous day's intake. Before the experiment began, a 2-wk acclimation period was set aside for cow adaptation to the experimental feeds. The experimental protocol was approved by the Animal Care committee of Université Laval (Québec, Canada), and animals were cared for according to the guidelines of the Canadian Council of Animal Care (1993).

\section{Measurements and Sampling}

Silage, TMR, Orts, and $B W$. Feed intake was recorded daily. Silages and TMR were sampled on $\mathrm{d}$ 11,12 , and 13 of each period, and orts were sampled the following day. Samples were kept at $-20^{\circ} \mathrm{C}$ until chemical analyses. Cow BW was recorded on d 11 and 14 of each period.

Feces. Total fecal excretion was collected, weighed, and sampled twice daily (10 h post-feeding and before feeding the next morning) on d 11, 12, and 13. The first sample was kept at $4^{\circ} \mathrm{C}$ until the second sample was taken. The 2 samples from the same cow in the same 24 -h period were pooled in proportion to excretion and were immediately frozen at $-20^{\circ} \mathrm{C}$ until further analysis.

Table 2. Ingredients of experimental $\operatorname{diets}^{1}(\%$, DM basis)

\begin{tabular}{lccc}
\hline Ingredient & Control & LDTS & LDBP \\
\hline High-DCAD timothy silage $^{2}$ & 41.5 & 0 & 41.6 \\
Low-DCAD timothy silage $^{2}$ & 20.6 & 62.1 & 20.7 \\
Corn silage & 12.8 & 12.8 & 10.9 \\
Ground corn & 18.7 & 18.7 & 18.7 \\
Soybean meal & 2.8 & 2.8 & 0 \\
Corn gluten meal $_{\text {BioChlor }}^{3}$ & 2.8 & 2.8 & 0 \\
Minerals and vitamins A $^{4}$ & 0 & 0 & 7.8 \\
Minerals and vitamins B $^{5}$ & 0.8 & 0.8 & 0 \\
\hline
\end{tabular}

${ }^{1}$ Control $=$ high-DCAD treatment; LDTS $=$ low-DCAD treatment using a low-DCAD timothy silage; LDBP $=$ low-DCAD treatment using a fermentation by-product.

${ }^{2}$ See Table 1 for composition.

${ }^{3}$ BioChlor is an acidified fermentation by-product from Church and Dwight (Princeton, NJ).

${ }^{4}$ Mineral and vitamin composition (DM basis): $\mathrm{Ca}=16.28 \%$; $\mathrm{P}=$ $0.01 \% ; \mathrm{Na}=14.96 \% ; \mathrm{Cl}=23.04 \% ; \mathrm{Mg}=0.88 \% ; \mathrm{K}=0.05 \% ; \mathrm{S}=$ $0.02 \% ; \mathrm{Cu}=993 \mathrm{mg} / \mathrm{kg} ; \mathrm{Mn}=4 \mathrm{mg} / \mathrm{kg} ; \mathrm{Zn}=3,599 \mathrm{mg} / \mathrm{kg} ; \mathrm{Fe}=$ $1,500 \mathrm{mg} / \mathrm{kg} ; \mathrm{Co}=8.28 \mathrm{mg} / \mathrm{kg} ; \mathrm{I}=66.23 \mathrm{mg} / \mathrm{kg} ; \mathrm{Se}=110.08 \mathrm{mg} /$ $\mathrm{kg}$; vitamin $\mathrm{A}=1,382 \mathrm{IU} / \mathrm{kg}$; vitamin $\mathrm{D}=264 \mathrm{IU} / \mathrm{kg}$; vitamin $\mathrm{E}=$ $13,418 \mathrm{IU} / \mathrm{kg}$.

${ }^{5}$ Mineral and vitamin composition (DM basis): $\mathrm{Ca}=26.24 \% ; P=$ $0.01 \% ; \mathrm{Na}=0.04 \% ; \mathrm{Cl}=0.02 \% ; \mathrm{Mg}=1.42 \% ; \mathrm{K}=0.08 \% ; \mathrm{S}=$ $0.03 \% ; \mathrm{Cu}=1,601 \mathrm{mg} / \mathrm{kg} ; \mathrm{Mn}=7 \mathrm{mg} / \mathrm{kg} ; \mathrm{Zn}=5,801 \mathrm{mg} / \mathrm{kg} ; \mathrm{Fe}=$ $2,418 \mathrm{mg} / \mathrm{kg} ; \mathrm{Co}=13.34 \mathrm{mg} / \mathrm{kg} ; \mathrm{I}=106.74 \mathrm{mg} / \mathrm{kg} ; \mathrm{Se}=177.41 \mathrm{mg} /$ $\mathrm{kg}$; vitamin $\mathrm{A}=2,228 \mathrm{IU} / \mathrm{kg}$; vitamin $\mathrm{D}=425 \mathrm{IU} / \mathrm{kg}$; vitamin $\mathrm{E}=$ $21,626 \mathrm{IU} / \mathrm{kg}$. 
Urine. Catheters (24 mm, 75-mL balloon, Bardex Lubricath, C. R. Bard Inc., Covington, GA) were installed into the bladder of each cow on d 10. At feeding on d 11, catheters were connected to a container using polyvinyl chloride tubing. Light mineral oil $(50 \mathrm{~mL})$ and $1 \mathrm{~g}$ of thymol were added to the containers to prevent deterioration of urine (Delaquis and Block, 1995). Total collection of urine was done on d 11, 12, and 13 . Urine was weighed twice a day: $10 \mathrm{~h}$ after feeding and at feeding the next morning. Urine was sampled under the light mineral oil through polyvinyl chloride tubing. Volume mass was determined by weighing $1 \mathrm{~L}$ of urine. Two 50-mL samples per cow per sampling were immediately frozen at $-20^{\circ} \mathrm{C}$ until further analysis.

Blood Samples. On d 14 of each experimental period, blood samples were taken twice from the jugular vein: $30 \mathrm{~min}$ and $3 \mathrm{~h}$ after feeding. Blood samples were taken by venipuncture with a heparinized syringe balanced for electrolytes (PICO 50, London Scientific Ltd., London, Ontario, Canada) for immediate analysis of blood $\mathrm{pH}$, partial $\mathrm{CO}_{2}$ and $\mathrm{O}_{2}$ pressures, base excess, and whole-blood concentrations of $\mathrm{HCO}_{3}{ }^{-}, \mathrm{Na}^{+}, \mathrm{K}^{+}$, $\mathrm{Cl}^{-}$, and $\mathrm{Ca}^{2+}$ with an automated micro-blood gas analyzer (ABL 77, Radiometer, Copenhagen, Denmark). An average for each blood parameter from both blood samples was used for statistical analysis.

\section{Chemical Analyses}

Silages, TMR, and Orts. Silages, TMR, and ort samples were freeze-dried and ground in a Wiley mill (Arthur H. Thomas Co., Philadelphia, PA) to pass through a 1-mm screen. Orts and TMR were pooled proportionally to their original daily quantity by cow by period. Subsamples of dried and ground silages, TMR, and orts were analyzed for ADF and NDF using the Ankom $\left(\right.$ Ankom $^{200}$ Fiber Analyzer, Fairport, NY) immersion method (Ankom Technology, 2005a,b). For NDF, the method used included the addition of sodium sulfite $(20 \mathrm{~g})$ in the neutral detergent solution and of $\alpha$-amylase $(4 \mathrm{~mL})$ for the first and second rinses. Subsamples of dried and ground silages, TMR, and orts were mineralized using a mixture of sulfuric and selenious acids as described by Isaac and Johnson (1976). This extract was used to determine CP, P, K, and $\mathrm{Mg}$. Concentration of $\mathrm{CP}$ was determined using total N (method 13-107-6-2-E; Lachat Instrument, 2005) that was measured using a Lachat QuikChem8000 flow injection analysis system (Zellweger Analytics Inc., Lachat Instruments Division, Milwaukee, WI). Total P (method no. 15-115-01-4-A; Lachat Instrument, 2005) was measured simultaneously with N. Flame emission was used to determine $\mathrm{K}$ concentration, and $\mathrm{Mg}$ concentration was determined by atomic absorption spec- trometry using the same spectrophotometer (Perkin Elmer 3300, Überlingen, Germany).

Subsamples of dried and ground silages, TMR, and orts were mineralized at $500^{\circ} \mathrm{C}$ for $4 \mathrm{~h}$. Ashes were dissolved with 1.0 N HCl (Miller, 1998). Concentrations of $\mathrm{Na}$ and $\mathrm{Ca}$ were determined by atomic absorption spectrometry (Perkin Elmer 3300, Überlingen, Germany). Subsamples of dried and ground silages, TMR, and orts were mixed with $20 \mathrm{~mL}$ of $0.0007 M$ sulfuric acid (Liu, 1998) for $60 \mathrm{~min}$, centrifuged at 32,570 $\times \mathrm{g}$ for $30 \mathrm{~min}$, and the $\mathrm{Cl}$ concentration of the supernatant was determined by conductivity on a Dionex DX500 equipped with a AS11HC column (Dionex Corp., Sunnyvale, CA). Subsamples of dried and ground silages, TMR, and orts were digested in nitric acid (Mills and Jones, 1996). Organic and inorganic forms of S were converted to a sulfate form that was precipitated with acidified barium chloride, suspended in a colloidal form, and analyzed by turbidimetry (adaptation of method 10-116-10-1-G; Lachat Instrument, 2005) on a Lachat QuikChem 8000 flow injection analysis system (Zellweger Analytics Inc.). Daily intake of ADF, NDF, $\mathrm{CP}, \mathrm{K}, \mathrm{Na}, \mathrm{Cl}, \mathrm{S}, \mathrm{Ca}, \mathrm{P}$, and $\mathrm{Mg}$ was calculated by subtracting ort from TMR nutrients.

Feces. Fecal samples were freeze-dried and ground in a Wiley mill (Arthur H. Thomas Co.) to pass through a 1-mm screen. Subsamples were pooled by cow and period, in proportion to daily fecal excretion. Feces were then analyzed for $\mathrm{ADF}, \mathrm{NDF}, \mathrm{CP}, \mathrm{K}, \mathrm{Na}, \mathrm{Cl}, \mathrm{S}$, $\mathrm{Ca}, \mathrm{P}$, and $\mathrm{Mg}$ using procedures described previously for forages, TMR, and orts. Daily excretion of ADF, $\mathrm{NDF}, \mathrm{CP}, \mathrm{K}, \mathrm{Na}, \mathrm{Cl}, \mathrm{S}, \mathrm{Ca}, \mathrm{P}$, and $\mathrm{Mg}$ was calculated by multiplying fecal excretion by its nutrient concentration. Apparent digestion of $\mathrm{ADF}, \mathrm{NDF}, \mathrm{CP}$ and the apparent absorption of $\mathrm{K}, \mathrm{Na}, \mathrm{Cl}, \mathrm{S}, \mathrm{Ca}, \mathrm{P}$, and $\mathrm{Mg}$ were calculated by subtracting nutrient daily excretion in feces from daily intake.

Urine. Urine $\mathrm{pH}$ was taken immediately after sampling (Oakton pH 10 Series, Vernon Hills, IL). Thawed subsamples of urine were pooled by cow and period proportionally to the urine excreted. Analysis of N, K, $\mathrm{Na}, \mathrm{Cl}, \mathrm{S}, \mathrm{Ca}, \mathrm{P}$, and $\mathrm{Mg}$ were then completed without any mineralization, using procedures described previously for forages, TMR, and orts. Apparent retention of $\mathrm{N}, \mathrm{K}, \mathrm{Na}, \mathrm{Cl}, \mathrm{S}, \mathrm{Ca}, \mathrm{P}$, and $\mathrm{Mg}$ were calculated by subtracting nutrient daily excretion in feces and urine from daily intake.

\section{Statistical Analyses}

Mixed model procedures from SAS version 9.1 (SAS Institute, 2002) for a replicated $3 \times 3$ Latin square design were used to evaluate the effect of dietary treatments on parameters. Raw data were transformed 
Table 3. Body weight, DMI, feces and urine production, and urine $\mathrm{pH}$ of cows fed diets with different levels of DCAD obtained by using a lowDCAD timothy silage or an anionic fermentation by-product

\begin{tabular}{|c|c|c|c|c|c|c|c|}
\hline \multirow[b]{2}{*}{ Item } & \multicolumn{3}{|c|}{ Treatment $(\operatorname{trt})^{1}$} & \multirow[b]{2}{*}{$\mathrm{SE}$} & \multirow[b]{2}{*}{$P$-value (trt) } & \multicolumn{2}{|c|}{ Contrast } \\
\hline & Control & LDTS & LDBP & & & $\begin{array}{c}\text { Control vs. } \\
\text { LDTS }\end{array}$ & $\begin{array}{l}\text { LDTS vs. } \\
\text { LDBP }\end{array}$ \\
\hline $\mathrm{BW}, \mathrm{kg}$ & 839 & 831 & 819 & 35.7 & 0.02 & 0.16 & 0.06 \\
\hline DMI, kg/d & 12.5 & 10.6 & 10.7 & 0.98 & 0.10 & 0.06 & 0.95 \\
\hline DMI/BW, \% & 1.49 & 1.28 & 1.30 & 0.109 & 0.13 & 0.07 & 0.84 \\
\hline Feces, $\mathrm{kg}$ of $\mathrm{DM} / \mathrm{d}$ & 3.86 & 3.61 & 3.13 & 0.318 & 0.03 & 0.28 & 0.06 \\
\hline Urine volume, L/d & 13.68 & 13.05 & 15.87 & 1.628 & 0.06 & 0.56 & 0.03 \\
\hline Urine $\mathrm{pH}$ & 8.18 & 6.15 & 5.98 & 0.086 & $<0.001$ & $<0.001$ & 0.06 \\
\hline
\end{tabular}

${ }^{1}$ Control = high DCAD treatment; LDTS = low DCAD treatment using low-DCAD timothy silage; LDBP = low DCAD treatment using a fermentation by-product.

(apparent absorption of $\mathrm{S}$ in $\mathrm{g} / \mathrm{d}$ and apparent digestion of ADF as a percentage of intake = log; apparent absorption of $\mathrm{S}$ as a percentage of intake $=\mathrm{x}^{2} ; \mathrm{S}$ and $\mathrm{P}$ in urine, and $\mathrm{Cl}$ in feces $=1 / \mathrm{x}$ ) when it was deemed appropriate to meet homogeneity of variance criteria. Cows were defined as a random effect, and Akaike's information criterion was used to select the best covariance structure among compound symmetry, first-order autoregressive, and unstructured. Orthogonal contrasts were defined a priori and used to compare 1) control versus LDTS treatments and 2) LDTS versus LDBP treatments. Differences between treatments were declared significant when $P$-values were $\leq 0.05$; statistical tendencies were noted for $0.05<P<0.10$.

\section{RESULTS AND DISCUSSION}

\section{Low-DCAD Timothy Silage to Decrease the DCAD of Rations}

Low-DCAD timothy silage decreased the DCAD of the ration $(P<0.001$; Table 1$)$ to a level where cows were in a compensated metabolic acidosis state as confirmed by decreases in urine $\mathrm{pH}$ (Table 3), blood $\mathrm{pH}$ (Table 4), $\mathrm{HCO}_{3}{ }^{-}$(Table 4), and base excess (Table 4) when fed LDTS compared with the control. The LDTS treatment did not result in a respiratory mechanism to compensate for the metabolic acidosis; there were similar levels of blood partial pressure for $\mathrm{O}_{2}$ and $\mathrm{CO}_{2}$ (Table 4). The lack of difference in the anion gap (Table 4) between LDTS and the control treatment also suggests that the metabolic acidosis created by LDTS was relatively mild. These results are comparable with those of Charbonneau et al. (2006) from a meta-analysis on the effects of decreasing DCAD on dry cows. The metabolic acidosis created by LDTS did not significantly increase blood $\mathrm{Ca}^{2+}$ (Table 4) and had no effect on Ca apparent absorption (Table 5) but it did increase Ca excretion in urine (Table 5), which points to a Ca mobilization from bones. This Ca mobilization from bone should decrease the susceptibility of cows to hypocalcemia at calving and indicates that low-DCAD silage could be used to produce a mild metabolic acidosis to prevent milk fever.

The tendency for lower DMI with LDTS (Table 3) resulted in a tendency for lower total DM, ADF, and NDF ingested and digested $(\mathrm{kg} / \mathrm{d}$; Table 6$)$. A decrease in nutrient intake is generally associated with lowDCAD diets (Oetzel and Barmore, 1993) but has not been observed in experiments evaluating low-DCAD timothy hay (Charbonneau et al., 2008; Penner et al., 2008). The decrease in DMI with low-DCAD silage could indicate that the method of conservation influences the DMI of cows fed low-DCAD forage. Given that digestibility was lower as a percentage of intake for total DM and ADF (Table 6), there may also be a difference in the quality of conservation between the high- and the low-DCAD timothy silage in the present experiment. In low- versus high-DCAD timothy silages, respectively, $\mathrm{pH}$ was $3.84 \pm 0.02$ versus $4.25 \pm 0.07$ (mean \pm SD); lactic acid: $15.96 \pm 0.17$ versus $19.85 \pm$ $0.41 \mathrm{~g} / \mathrm{kg}$ of DM; acetic acid: $4.49 \pm 0.36$ versus $4.81 \pm$ $0.16 \mathrm{~g} / \mathrm{kg}$ of DM; propionic acid: $0.07 \pm 0.02$ versus 0.08 $\pm 0.003 \mathrm{~g} / \mathrm{kg}$ of DM; and no butyric acid. Even though $\mathrm{pH}$ and lactic acid concentration differences between both silages indicate variations during the fermentation process, they were not in a problematic range. Both silages were managed in the same way and had similar chemical compositions (Table 1). Many factors could be responsible for the difference in fermentation including buffering capacities and the higher $\mathrm{Cl}$ concentration in the low-DCAD silage. Chlorine is known for its antibacterial proprieties but the experimental design used in this trial did not allow for the verification of the 
Table 4. Blood parameters in cows fed diets with different levels of DCAD obtained by using a low-DCAD timothy silage or an anionic fermentation by-product

\begin{tabular}{|c|c|c|c|c|c|c|c|}
\hline \multirow[b]{2}{*}{ Parameter } & \multicolumn{3}{|c|}{ Treatment (trt) ${ }^{1}$} & \multirow[b]{2}{*}{$\mathrm{SE}$} & \multirow[b]{2}{*}{$P$-value (trt) } & \multicolumn{2}{|c|}{ Contrast } \\
\hline & Control & LDTS & LDBP & & & Control vs. LDTS & LDTS vs. LDBP \\
\hline $\mathrm{Ca}^{2+}, \mathrm{mg} / \mathrm{dL}$ & 5.21 & 5.30 & 5.41 & 0.059 & 0.02 & 0.13 & 0.06 \\
\hline $\mathrm{pH}$ & 7.42 & 7.37 & 7.33 & 0.011 & $<0.01$ & $<0.01$ & 0.03 \\
\hline $\mathrm{pCO}_{2},{ }^{2} \mathrm{~mm} \mathrm{Hg}$ & 43 & 44 & 43 & 1.7 & 0.81 & 0.58 & 0.58 \\
\hline $\mathrm{pO}_{2},{ }^{3} \mathrm{~mm} \mathrm{Hg}$ & 30 & 32 & 31 & 1.1 & 0.27 & 0.11 & 0.42 \\
\hline $\mathrm{HCO}_{3}{ }^{-4}, \mathrm{mM}$ & 27.5 & 25.3 & 21.5 & 0.58 & $<0.001$ & $<0.01$ & $<0.001$ \\
\hline $\mathrm{K}^{+}, \mathrm{mEq} / \mathrm{L}$ & 3.9 & 3.8 & 4.0 & 0.11 & 0.56 & 0.64 & 0.29 \\
\hline $\mathrm{Cl}^{-}, \mathrm{mEq} / \mathrm{L}$ & 103 & 105 & 107 & 0.5 & $<0.001$ & 0.01 & $<0.001$ \\
\hline Anion gap, $\mathrm{mEq} / \mathrm{L}^{5}$ & 12.3 & 12.4 & 15.3 & 0.31 & $<0.001$ & 0.80 & $<0.001$ \\
\hline
\end{tabular}

${ }^{1}$ Control $=$ high DCAD treatment; LDTS $=$ low DCAD treatment using low-DCAD timothy silage; LDBP $=$ low DCAD treatment using a fermentation by-product.

${ }^{2}$ Partial pressure of $\mathrm{CO}_{2}$.

${ }^{3}$ Partial pressure of $\mathrm{O}_{2}$.

${ }^{4}$ Bicarbonate.

${ }^{5}$ Anion gap $=\mathrm{K}^{+}+\mathrm{Na}^{+}-\mathrm{Cl}^{-}-\mathrm{HCO}_{3}^{-}$.

effect of $\mathrm{Cl}$ fertilization on forage fermentation; more research is needed to determine how low-DCAD forage is affected by silage fermentation.

Apparent absorption of $\mathrm{K}$ as a percentage of intake (Table 7), especially for both low-DCAD treatments, was lower than the $90 \%$ expected (NRC, 2001). Lower
$\mathrm{K}$ apparent absorption as a percentage of intake has also been reported as a tendency when ration DCAD was decreased using a low-DCAD timothy hay or $\mathrm{HCl}$ (Charbonneau et al., 2008). Negative DCAD values might decrease $\mathrm{K}$ absorption as a percentage of intake but further study with pregnant cows is needed to

Table 5. Intake, excretion in feces and urine, apparent absorption, and apparent retention of Ca, $\mathrm{P}$, and $\mathrm{Mg}$ in cows fed diets with different levels of DCAD obtained by using a low-DCAD silage or an anionic fermentation by-product

\begin{tabular}{|c|c|c|c|c|c|c|c|}
\hline \multirow[b]{2}{*}{ Item } & \multicolumn{3}{|c|}{ Treatment $^{1}$} & \multirow[b]{2}{*}{$\mathrm{SE}$} & \multirow[b]{2}{*}{$\begin{array}{c}P \text {-value } \\
\text { (trt) }\end{array}$} & \multicolumn{2}{|c|}{ Contrast } \\
\hline & Control & LDTS & LDBP & & & $\begin{array}{l}\text { Control vs. } \\
\text { LDTS }\end{array}$ & $\begin{array}{l}\text { LDTS vs. } \\
\text { LDBP }\end{array}$ \\
\hline Intake, g/d & 54.9 & 58.5 & 46.9 & 5.10 & 0.14 & 0.51 & 0.06 \\
\hline Feces, g/d & 54.9 & 55.8 & 39.1 & 4.96 & $<0.001$ & 0.73 & $<0.001$ \\
\hline Absorbed, g/d & 3.9 & 2.0 & 4.5 & 3.32 & 0.89 & 0.76 & 0.75 \\
\hline Retained, g/d & 1.2 & -10.2 & -6.1 & 3.27 & 0.13 & 0.05 & 0.45 \\
\hline Retained, \% intake & 2.5 & -20.6 & -12.3 & 7.51 & 0.19 & 0.08 & 0.50 \\
\hline \multicolumn{8}{|l|}{$\mathrm{P}$} \\
\hline Intake, g/d & 37.1 & 29.4 & 34.2 & 2.92 & 0.09 & 0.04 & 0.15 \\
\hline Feces, g/d & 36.9 & 33.1 & 33.9 & 3.40 & 0.26 & 0.13 & 0.73 \\
\hline Absorbed, g/d & -0.1 & -3.6 & 0.5 & 1.20 & 0.03 & 0.03 & 0.01 \\
\hline Absorbed, \% intake & -0.4 & -11.5 & 2.1 & 9.39 & $<0.01$ & 0.01 & $<0.01$ \\
\hline Feces, g/d & 14.2 & 14.5 & 14.1 & 1.17 & 0.91 & 0.77 & 0.69 \\
\hline Absorbed, g/d & 3.4 & 3.2 & 2.5 & 0.58 & 0.47 & 0.81 & 0.35 \\
\hline Absorbed, \% intake & 18.8 & 17.6 & 15.2 & 2.64 & 0.57 & 0.75 & 0.48 \\
\hline Urine, $\mathrm{g} / \mathrm{d}$ & 3.1 & 3.7 & 1.5 & 0.41 & $<0.01$ & 0.17 & $<0.001$ \\
\hline Retained, g/d & 0.3 & -0.5 & 1.0 & 0.39 & 0.04 & 0.14 & 0.01 \\
\hline Retained, \% intake & 1.3 & -3.2 & 7.0 & 2.29 & 0.02 & 0.15 & $<0.01$ \\
\hline
\end{tabular}

${ }^{1}$ Control $=$ high DCAD treatment; LDTS $=$ low DCAD treatment using low-DCAD timothy silage; LDBP $=$ low DCAD treatment using a fermentation by-product. 
Table 6. Fiber and $\mathrm{N}$ intakes, concentrations of fiber and $\mathrm{N}$ in feces, apparent digestion of fiber, $\mathrm{N}$ and total DM, and $\mathrm{N}$ apparent retention in cows fed diets with different levels of DCAD obtained by using a low-DCAD timothy silage or an anionic fermentation by-product

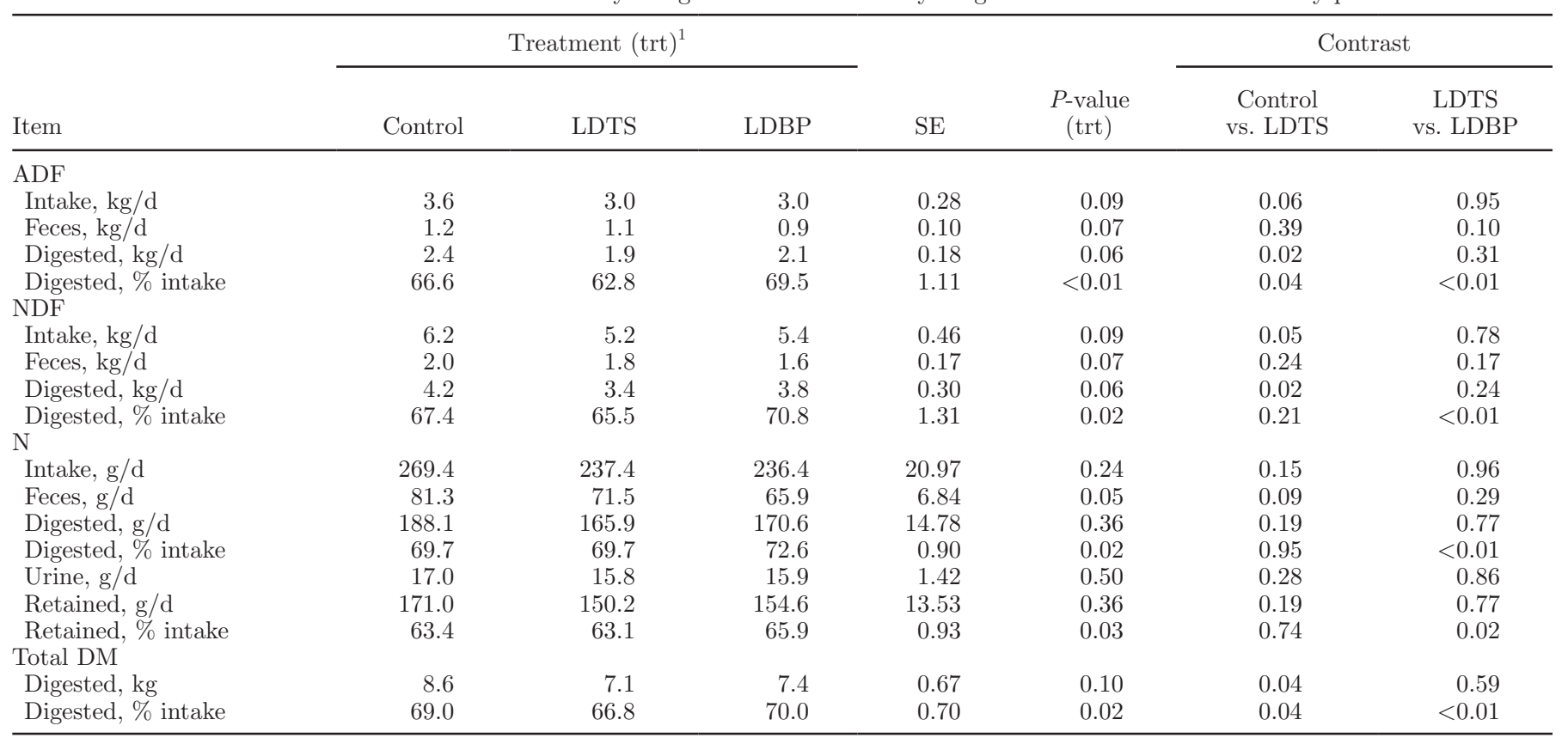

${ }^{1}$ Control $=$ high DCAD treatment; LDTS $=$ low DCAD treatment using low-DCAD timothy silage; LDBP $=$ low DCAD treatment using a fermentation by-product.

confirm this hypothesis. Lower quantities of apparently absorbed $\mathrm{K}$ and lower $\mathrm{K}$ excreted in urine (Table 7), both expressed in grams per day, might be explained by the lower K intake for LDTS compared with the control and the need for $\mathrm{K}$ in a renal regulation mechanism; $\mathrm{K}$ is closely related to $\mathrm{Na}$ and $\mathrm{Cl}$ excretion and reabsorption in renal tissue (Rose and Post, 2001) and could have been needed for the equilibrium of charge with $\mathrm{Cl}^{-}$in renal tubular lumen. Lower values for apparently retained $\mathrm{K}$ (Table 7) were unexpected and differ from other experiments (Delaquis and Block, 1995; Charbonneau et al., 2008).

Apparent absorption of $\mathrm{Na}$ as a percentage of intake was low for all treatments; the control treatment had the lowest value at $45.3 \%$ (Table 7). Low levels of absorption have been previously reported (Leclerc and Block, 1989; Delaquis and Block, 1995; Charbonneau et al., 2008) and are likely related to the nonlactating status of the cows. The increase in Na absorption in grams per day and as a percentage of intake and the decrease in $\mathrm{Na}$ in feces (Table 7) when cows were fed LDTS compared with the control treatment probably comes from the close regulation of $\mathrm{Na}$ and $\mathrm{Cl}$ and the higher $\mathrm{Cl}$ intake (Table 7) with LDTS. Because $\mathrm{Cl}$ regulation is mainly through urine (Underwood and Suttle, 1999), higher Cl apparent absorption $(\mathrm{g} / \mathrm{d}$; Table 7$)$, higher $\mathrm{Cl}$ in feces (Table 7), higher $\mathrm{Cl}$ concentration in blood (Table 4), and higher $\mathrm{Cl}$ excreted in urine (Table 7) would also be largely due to the higher $\mathrm{Cl}$ intake for cows fed LDTS compared with the control. No significant differences were observed between the control and LDTS for sulfur intake, absorption, or retention in feces and in urine.

Negative or near-zero values were obtained for all dietary treatments for the apparent absorption and retention of $\mathrm{P}$ (Table 5). Negative values for $\mathrm{P}$ retention are not common in dry cows, but negative or near-zero $\mathrm{P}$ balances have been reported for nonpregnant multiparous cows (Wang and Beede, 1990). When normal amounts of $\mathrm{P}$ are fed, passive process may constitute an important pathway for $\mathrm{P}$ absorption (NRC, 2001). Mechanisms for active transport of $\mathrm{P}$ would not have been promoted in this experiment because the need for $\mathrm{P}$ was low for nonpregnant and nonlactating cows. The amount of $\mathrm{P}$ passively absorbed relates to the amount available for absorption in the small intestine and to concentration in blood plasma (NRC, 2001). In the present study, less exogenous $\mathrm{P}$ was available in the intestine for LDTS because less $\mathrm{P}$ was ingested (Table 5) and less DM was digested (Table 6) than with the control. This might explain, in part, the lower apparent absorption of $\mathrm{P}$ (Table 5) in grams per day and as a percentage of intake when the LDTS diet was fed. Furthermore, the increased bone mobilization of $\mathrm{Ca}$ and $\mathrm{P}$ caused by the mild metabolic acidosis induced by LDTS might also have decreased the apparent absorption of P. During bone mobilization, Ca and P 
Table 7. Intake, excretion in feces and urine, apparent absorption, and apparent retention of $\mathrm{K}, \mathrm{Na}, \mathrm{Cl}$, and $\mathrm{S}$ in cows fed diets with different levels of DCAD obtained by using a low-DCAD timothy silage or an anionic fermentation by-product

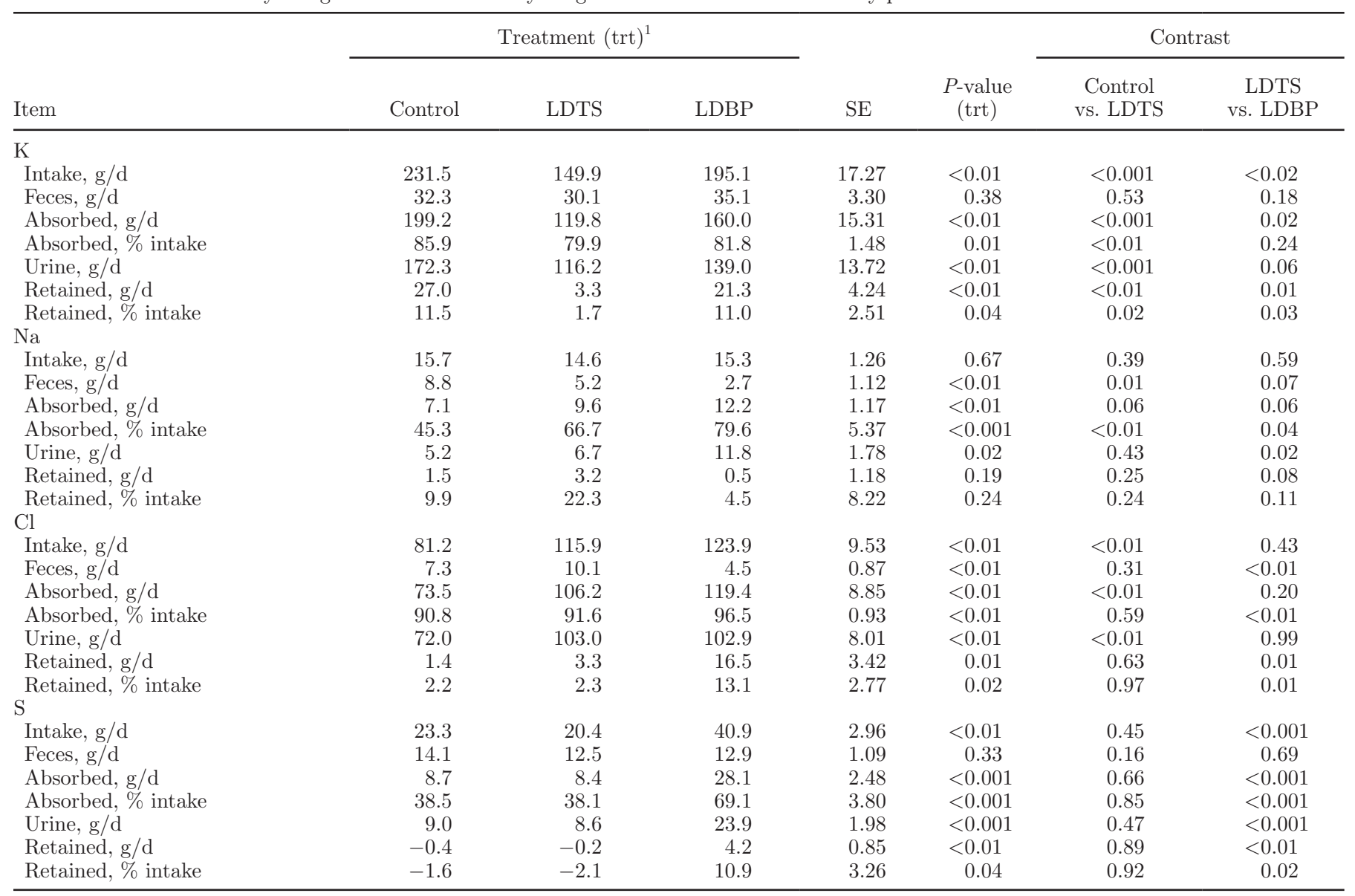

${ }^{1}$ Control $=$ high DCAD treatment; LDTS $=$ low DCAD treatment using low-DCAD timothy silage; LDBP $=$ low DCAD treatment using a fermentation by-product.

ions are released into blood circulation. A low-DCAD ration for lactating cows has been shown to result in a higher concentration of plasma $\mathrm{P}$ (Borucki Castro et al., 2004), which is associated with more $\mathrm{P}$ in the saliva (Valk et al., 2002). Phosphorus homeostasis is maintained primarily by its secretion in the digestive tract for reabsorption or excretion in feces (Pfeffer et al., 2005). Most of the difference in $\mathrm{P}$ retention (Table 5 ) between these 2 treatments, in grams per day and as a percentage of intake, could be explained by the difference in $\mathrm{P}$ absorption. Only a few studies investigate the effect of decreasing DCAD on $\mathrm{P}$ apparent absorption. The decrease in $\mathrm{P}$ absorption with a decrease in DCAD has not been observed in dry cows (Delaquis and Block, 1995; Charbonneau et al., 2008) nor in lactating cows (Borucki Castro et al., 2004), but among these previous studies, only Charbonneau et al. (2008) reports a DCAD level lower than $100 \mathrm{mEq} / \mathrm{kg}$ of DM. Also, because of milk production, lactating cows in the Borucki Castro et al. (2004) experiment were in a negative $\mathrm{P}$ balance for all treatments. This may explain the lack of variation in $\mathrm{P}$ absorption with the decrease in DCAD. More research is needed to better understand the effect of negative DCAD on $\mathrm{P}$ absorption.

\section{Comparison of Low-DCAD Treatments}

The DCAD of LDTS and LDBP did not differ $(P$ $=0.38$ ) and both diets had a DCAD value (Table 1 ) at the recommended level of $0 \mathrm{mEq} / \mathrm{kg}$ of DM (Horst and Goff, 1997; NRC, 2001; Charbonneau et al., 2006) or lower. Decreasing the ration DCAD by using the low-DCAD timothy silage instead of the fermentation by-product achieved a urinary $\mathrm{pH}$ closer to the recommended level of 7 (NRC, 2001; Charbonneau et al., 2006). Urine pH was significantly lower when cows were fed LDBP instead of LDTS (Table 3), which indicates that the fermentation by-product induced a stronger metabolic acidosis in cows than LDTS. Blood attributes (Table 4) corroborate this finding; blood $\mathrm{pH}$, $\mathrm{HCO}_{3}{ }^{-}, \mathrm{Ca}^{2+}$ (tendency), and base excess were higher, and blood anion gap was lower for LDTS compared 
with the LDBP treatment. There was no difference in partial blood pressure of $\mathrm{CO}_{2}$ or $\mathrm{O}_{2}$ (Table 4), which suggests that none of these treatments increased the respiratory response of animals (Rose and Post, 2001). These results show that low-DCAD timothy silage is a plausible alternative to decrease DCAD and induce a compensated metabolic acidosis; however, its acidifying capacity is not as strong as the fermentation by-product. The lower K concentration in low-DCAD timothy silage (Table 1) decreases the need for anions to lower DCAD and might explain the lesser effect on cow metabolism. The levels of both feeds should be adjusted to obtain adequate urinary $\mathrm{pH}$ at the beginning of the transition period.

Both LDTS and LDBP resulted in similar DMI. Apparent digestibility as a percentage of intake for DM, ADF, NDF, and N (Table 6) was lower when LDTS was fed compared with when LDBP was fed. Increases in $\mathrm{CP}$ and $\mathrm{OM}$ digestibility were also reported in continuous culture fermenters when the same fermentation by-product was used (Lean et al., 2005).

Intake of $\mathrm{K}$ was lower when cows were fed LDTS instead of LDBP, which explains the lower apparent absorption (g/d), urine excretion, and apparent retention (in $\mathrm{g} / \mathrm{d}$ ) of K with LDTS treatment (Table 7 ). The lower apparent retention as a percentage of intake with LDTS might be related to the lower intake and the need for $\mathrm{K}$ in renal regulation. Lower $\mathrm{Na}$ apparent absorption, in grams per day and as a percentage of intake, for cows fed LDTS instead of LDBP is probably because of the close regulation of $\mathrm{Na}$ and $\mathrm{Cl}$ and the numerically lower $\mathrm{Cl}$ absorption for LDTS. An increase in $\mathrm{Cl}$ absorption as a percentage of intake (Table 7) with LDBP is probably due to the higher bioavailability of $\mathrm{Cl}$ from the fermentation by-product, which resulted in higher blood $\mathrm{Cl}^{-}$(Table 4). Urinary Na was lower with LDTS than with LDBP (Table 7). An explanation for this result could be that $\mathrm{Na}$ was not reabsorbed as well with LDBP because it compensated for the higher negative charges of $\mathrm{S}$ in the urine. This additional anion in the urine would have been compensated for by an increase in the reabsorption of other anions or by a decrease in cationic reabsorption. Results from our experiment indicate that less $\mathrm{Na}$ and more $\mathrm{Cl}$ were reabsorbed with LDBP because more $\mathrm{Na}$ was found in the urine and more $\mathrm{Cl}$ was retained by cows when this treatment was fed than with LDTS (Table 7). Because $\mathrm{H}_{2} \mathrm{O}$ is mostly reabsorbed with $\mathrm{Na}$, the diminution in $\mathrm{Na}$ reabsorption could explain the increase in urine volume with LDBP. Vagnoni and Oetzel (1998) also observed higher Na excretion with the same anionic by-product compared with a control or 2 anionic salt mixtures $\left(\mathrm{MgSO}_{4} \cdot 7 \mathrm{H}_{2} \mathrm{O}\right.$ $\left.+\mathrm{NH}_{4} \mathrm{Cl} ; \mathrm{MgSO}_{4} \cdot 7 \mathrm{H}_{2} \mathrm{O}+\mathrm{CaCl}_{2} \cdot 2 \mathrm{H}_{2} \mathrm{O}+\mathrm{CaSO}_{4}\right)$. In their experiment, there was also a greater concentration of $\mathrm{Na}$ in the diet using the anionic by-product. These authors also reported that $\mathrm{MgSO}_{4} \cdot 7 \mathrm{H}_{2} \mathrm{O}+\mathrm{CaCl}_{2} \cdot 2 \mathrm{H}_{2} \mathrm{O}$ $+\mathrm{CaSO}_{4}$ mixture resulted in high sulfur excretion in urine but $\mathrm{Na}$ excretion was not increased. However, the strong ions difference $\left[\left(\mathrm{Na}^{+}+\mathrm{K}^{+}\right)-\left(\mathrm{Cl}^{-}+\mathrm{S}^{2-}\right) ; \mathrm{mEq}\right]$ of urine was not different between the 2 treatments, which does not negate the previous theory. The decrease in renal $\mathrm{H}_{2} \mathrm{O}$ reabsorption could explain the higher fecal DM (Table 3) for LDBP compared with LDTS. For the same DCAD level, this anionic fermentation by-product seems to induce a stronger metabolic acidosis in cows than other low-DCAD treatments; this could be the result of higher bioavailability of $\mathrm{Cl}$ and $\mathrm{S}$ for dry cows fed this product compared with other products used to decrease DCAD. Delaquis and Block (1995) evaluated the effect of low DCAD on renal mechanism. They observed a decrease in urine volume with a decrease in DCAD but did not observe important variations in other parameters; however, their lowest DCAD value was $327 \mathrm{mEq} / \mathrm{kg}$ of DM.

Lower apparent absorption and retention for $\mathrm{P}$ and $\mathrm{S}$ (Table 5), in grams per day and as a percentage of intake, for cows fed LDTS instead of LDBP is probably due to higher concentrations and differences in the bioavailability of these minerals in the fermentation by-product compared with soybean meal, corn gluten meal, and corn silage. An increase in urinary S (Table 7) and a decrease in urinary $\mathrm{Mg}$ (Table 5) were also observed by Vagnoni and Oetzel (1998) with the same fermentation by-product. The increase in $\mathrm{S}$ urinary excretion with LDBP might be the result of increased S intake (Table 7) and absorption (Table 7). In the current study and in Vagnoni and Oetzel (1998), a decrease in urine $\mathrm{Mg}$ concentration was observed when cows were fed a low-DCAD ration supplemented with the same fermentation by-product compared with a control diet or low-DCAD diets supplemented with mixtures of anionic salts $\left(\mathrm{MgSO}_{4} \cdot 7 \mathrm{H}_{2} \mathrm{O}+\mathrm{NH}_{4} \mathrm{Cl} ; \mathrm{MgSO}_{4} \cdot 7 \mathrm{H}_{2} \mathrm{O}+\right.$ $\left.\mathrm{CaCl}_{2} \cdot 2 \mathrm{H}_{2} \mathrm{O}+\mathrm{CaSO}_{4}\right)$. Therefore, differences in urine and apparent retention of $\mathrm{Mg}$ seem to be related to this fermentation by-product in the diet although the exact mechanism has not been identified. The greater amount of Ca excreted in feces (Table 5) for cows fed LDTS compared with LDBP is probably the result of a numerically higher Ca intake (Table 5). Both treatments had negative Ca retention (Table 5), which is typical of low-DCAD diets (Gaynor et al., 1989; Van Mosel et al., 1993; Schonewille et al., 1994a).

\section{CONCLUSIONS}

Results from this experiment indicate that a lowDCAD timothy silage $(-51 \mathrm{mEq} / \mathrm{kg}$ of $\mathrm{DM})$, produced through soil fertilization with chloride, can be fed to 
nonlactating cows to induce a compensated metabolic acidosis, which was confirmed by a decrease in urine $\mathrm{pH}$, blood $\mathrm{pH}, \mathrm{HCO}_{3}{ }^{-}$, and base excess. At a similar DCAD level, the commercial fermentation by-product induced a stronger metabolic acidosis. The low-DCAD timothy silage had negative effects on DMI and DM digestibility that were not observed in a previous experiment for low-DCAD timothy hay. More research is needed to better understand the effect of low-DCAD forage on the silage fermentation process. Moreover, a direct comparison between low-DCAD hay and silage would help to assess their respective effects on DMI. The utilization of both low-DCAD timothy silage and the commercial fermentation by-product affected the absorption and retention of major minerals. Further research is needed to clarify these variations. Low-DCAD timothy silage could provide an interesting alternative to anionic products for inducing a compensated metabolic acidosis, which lowers the risk of hypocalcemia at calving.

\section{ACKNOWLEDGMENTS}

This study was supported by a grant from the Action concertée FQRNT-Novalait-MAPAQ (FQRNT = Fonds Québecois de la Recherche sur la Nature et les Technologies; MAPAQ = Ministère de l'Agriculture, des Pêcheries et de l'Alimentation du Québec) in collaboration with Agriculture and Agri-Food Canada, and a scholarship from FQRNT. The authors thank Annie Brégard of Université Laval for her help during the experiment. Also, sincere appreciation is expressed to the staff of the Centre de Recherche en Sciences Animales de Deschambault, the institution where the experiment took place. Thanks go to Mario Laterrière from Agriculture and Agri-Food Canada, Québec, for laboratory assistance. Appreciation is also extended to Rachel Gervais and Andrée-Anne Gingras, graduate students, as well as François Bécotte, undergraduate student, at Université Laval, for their help during sample collections.

\section{REFERENCES}

Ankom Technology. 2005a. Acid detergent fiber in feeds; Filter bag technique. Ankom Technology, Macedon, NY.

Ankom Technology. 2005b. Neutral detergent fiber in feeds; Filter bag technique. Ankom Technology, Macedon, NY.

Borucki Castro, S. I., L. E. Phillip, V. Girard, and A. Tremblay. 2004. Altering dietary cation-anion difference in lactating dairy cows to reduce phosphorus excretion to the environment. J. Dairy Sci. $87: 1751-1757$.

Broderick, G. A. 1985. Alfalfa silage or hay versus corn silage as the sole forage for lactating dairy cows. J. Dairy Sci. 68:3262-3271.

Canadian Council of Animal Care. 1993. Guide to the Care and Use of Experimental Animals. Vol. 1. 2nd ed. CCAC, Ottawa, Ontario, Canada.
Charbonneau, E., P. Y. Chouinard, G. F. Tremblay, G. Allard, and D. Pellerin. 2008. Hay to reduce dietary cation-anion difference for dry dairy cows. J. Dairy Sci. 91:1585-1596.

Charbonneau, E., D. Pellerin, and G. R. Oetzel. 2006. Impact of lowering dietary cation-anion difference in nonlactating dairy cows: A meta-analysis. J. Dairy Sci. 89:537-548.

Delaquis, A. M., and E. Block. 1995. Acid-base status, renal function, water, and macromineral metabolism of dry cows fed diets differing in cation-anion difference. J. Dairy Sci. 78:604-619.

Dishington, I. W. 1975. Prevention of milk fever (hypocalcemic paresis puerperalis) by dietary salt supplements. Acta Vet. Scand. 16:503-512.

Gaynor, P. J., F. J. Mueller, J. K. Miller, N. Ramsey, J. P. Goff, and R. L. Horst. 1989. Parturient hypocalcemia in Jersey cows fed alfalfa haylage-based diets with different cation to anion ratios. J. Dairy Sci. 72:2525-2531.

Goff, J. P., and R. L. Horst. 1998. Use of hydrochloric acid as a source of anions for prevention of milk fever. J. Dairy Sci. 81:28742880

Goff, J. P., R. Ruiz, and R. L. Horst. 2004. Relative acidifying activity of anionic salts commonly used to prevent milk fever. J. Dairy Sci. $87: 1245-1255$

Horst, R. L., and J. P. Goff. 1997. Milk fever and dietary potassium. Pages 181-189 in Proc. 1997 Cornell Nutr. Conf. for Feed Manuf., Rochester, NY. Cornell Univ., Ithaca, NY.

Horst, R. L., J. P. Goff, T. A. Reinhardt, and D. R. Buxton. 1997. Strategies for preventing milk fever in dairy cattle. J. Dairy Sci 80:1269-1280

Huber, T. L., R. C. Wilson, A. J. Stattelman, and D. D. Goetsch. 1981. Effect of hypocalcemia on motility of the ruminant stomach. Am. J. Vet. Res. 42:1488-1489.

Isaac, R. A., and W. C. Johnson. 1976. Determination of total nitrogen in plant tissue, using a block digestor. J. Assoc. Off. Anal. Chem. 59:98-100

Kume, S., T. Toharmat, K. Nonaka, T. Oshita, T. Nakui, and J. H. Ternouth. 2001. Relationship between crude protein and mineral concentrations in alfalfa and value of alfalfa silage as a mineral source for periparturient cows. Anim. Feed Sci. Technol. 93:157168.

Lachat Instrument. 2005. Subject: Method list for automated ion analyzers (flow injection analyses, ion chromatography). www. lachatinstruments.com/applications/MethodsList.PDF. Accessed 18 Apr., 2005.

Lean, I. J., P. J. DeGaris, D. M. McNell, and E. Block. 2006. Hypocalcemia in dairy cows: Meta-analysis and dietary cation anion difference theory revisited. J. Dairy Sci. 89:669-684.

Lean, I. J., T. K. Miller Webster, W. Hoover, W. Chalupa, C. J. Sniffen, E. Evans, E. Block, and A. R. Rabiee. 2005. Effects of BioChlor and Fermenten on microbial protein synthesis in continuous culture fermenters. J. Dairy Sci. 88:2524-2536.

Leclerc, H., and E. Block. 1989. Effects of reducing dietary cationanion balance for prepartum dairy cows with specific reference to hypocalcemic parturient paresis. Can. J. Anim. Sci. 69:411-423.

Liu, L. 1998. Determination of chloride in plant tissue. Pages 111-113 in Handbook of Reference Methods for plant analysis. Y. P. Karla ed. CRC Press, Boca Raton, FL.

Miller, R. O. 1998. High temperature oxidation. Pages 53-56 in Handbook of Reference Methods for Plant Analysis. Y. P. Karla, ed. Soil and Plant Analysis Council Inc., CRC Press, Boca Raton, FL

Mills, H. A., and J. B. Jones Jr. 1996. Plant Analysis Handbook II A Practical Sampling, Preparation, Analysis, and Interpretation Guide. Rev. ed. MicroMacro Publishing Inc., Athens, GA.

National Research Council. 2001. Nutrient Requirements of Dairy Cattle. 7th ed. Natl. Acad. Press, Washington, DC.

Oetzel, G. R., and J. A. Barmore. 1993. Intake of a concentrate mixture containing various anionic salts fed to pregnant, nonlactating dairy cows. J. Dairy Sci. 76:1617-1623.

Oetzel, G. R., J. D. Olson, C. R. Curtis, and M. J. Fettman. 1988. Ammonium chloride and ammonium sulfate for prevention of parturient paresis in dairy cows. J. Dairy Sci. 71:3302-3309. 
Pelletier, S., G. Bélanger, G. F. Tremblay, P. Séguin, R. Drapeau, and G. Allard. 2007. Dietary cation-anion difference of timothy (Phleum pratense L.) as influenced by application of chloride and nitrogen fertilizer. Grass Forage Sci. 62:66-77.

Penner, G. B., G. F. Tremblay, T. Dow, and M. Oba. 2008. Timothy hay with a low dietary cation-anion difference improves calcium homeostasis in periparturient Holstein cows. J. Dairy Sci. 91:1959-1968.

Pfeffer, E., D. K. Beede, and H. Valk. 2005. Phosphorus metabolism in ruminants and requirements of cattle. Pages 195-231 in Nitrogen and phophorus nutrition of cattle. Reducing the environmental impact of the cattle operation. E. Pfeffer and A. Hristov, ed. CABI Publishing, Wallingford, UK.

Rose, D. B., and T. W. Post. 2001. Clinical Physiology of Acid-Base and Electrolyte Disorders. 5th ed. McGraw-Hill, New York, NY.

SAS Institute. 2002. System Software: Release 9.1 (TS1M3). SAS Institute Inc., Cary, NC.

Schonewille, J. T., A. T. Van't Klooster, and A. C. Beynen. 1994a. The addition of extra calcium to a chloride-rich ration does not affect the absolute amount of calcium absorbed by non-pregnant, dry cows. J. Anim. Physiol. Anim. Nutr. (Berl.) 72:272-280.

Schonewille, J. T., A. T. Van't Klooster, A. Dirkzwager, and A. C. Beynen. 1994b. Stimulatory effect of an anion (chloride)-rich ration on apparent calcium absorption in dairy cows. Livest. Prod. Sci 40:233-240.

Tremblay, G. F., H. Brassard, G. Bélanger, P. Séguin, R. Drapeau, A. Bregard, R. Michaud, and G. Allard. 2006. Dietary cation anion difference of five cool-season grasses. Agron. J. 98:339-348.

Underwood, E. J., and N. F. Suttle. 1999. The Mineral Nutrition of Livestock. 3rd ed. CABI Publishing, New York, NY.

Vagnoni, D. B., and G. R. Oetzel. 1998. Effects of dietary cationanion difference on the acid-base status of dry cows. J. Dairy Sci. 81:1643-1652.

Valk, H., B. J. Sebek, and A. C. Beynen. 2002. Influence of phosphorus intake on excretion and blood plasma and saliva concentrations of phosphorus in dairy cows. J. Dairy Sci. 85:2642-2649.

Van Mosel, M., A. T. Van't Klooster, F. Van Mosel, and J. Van der Kuilen. 1993. Effects of reducing dietary $\left[\left(\mathrm{Na}^{+}+\mathrm{K}^{+}\right)-\left(\mathrm{Cl}^{-}\right.\right.$ $\left.\left.+\mathrm{SO}_{4}=\right)\right]$ on the rate of calcium mobilisation by dairy cows at parturition. Res. Vet. Sci. 54:1-9.

Wang, C., and D. K. Beede. 1990. Effects of supplemental protein on acid-base status and calcium metabolism of nonlactating Jersey cows. J. Dairy Sci. 73:3178-3186. 